\title{
SAUDI ARABIA AND IRAN: THE BATTLE FOR HEGEMONY THAT THE KINGDOM CANNOT WIN
}

\section{REGIME SURVIVAL IN QUESTION}

The dawn of 2016 has brought a new round of doomsday predictions that Saudi Arabia's ruling Al Saud family cannot sustain its autocratic grip on power. The predictions build on a long-standing record of Western government officials, former intelligence officers, academics and pundits, concluding that Saudi Arabia's system of government, an absolute monarchy legitimized by ultra-conservative religious beliefs, is unsustainable.

Former US Central Intelligence Agency (CIA) operative Robert Baer warned in a book in 2003 that "the country is run by an increasingly dysfunctional royal family that has been funding militant Islamic movements abroad in an attempt to protect itself from them at home... Today's Saudi Arabia can't last much longer - and the social and economic fallout of its demise could be calamitous" (Baer, 2003). Baer and other officials and pundits may have erred in their predicted timelines, but many argue that the underlying assumption remains valid, no more so than today as the kingdom seemingly heads into a perfect storm of economic problems, social challenges, and foreign policy crises (Dorsey, 2016a).

Saudi Arabia may indeed be heading into a perfect storm, but the key drivers are likely to be far more existential. Those drivers, interlinked since the 1979 Iranian revolution, are the A1 Saud's increasingly problematic Faustian bargain between the A1 Sauds and descendants of $18^{\text {th }}$ century preacher Mohammed ibn Abdul Wahhab Commins (Commins, 2009), and Iran. In exchange for legitimizing the temporal rule of the Al Sauds, the Saudi Wahhabi clergy was allowed to impose the world's strictest, most restrictive and puritan interpretation of Islamic law and social mores and propagate globally an expansionist, discriminatory and anti-pluralistic theological approach that only recently has been matched, if not surpassed, by governance in the Islamic State (IS), jihadist-controlled chunks of Syria and Iraq.

Saudi government leaders have long sought to counter Iran by motivating Sunnis to fear and resist Iranian influence. Framing its rivalry with Iran in sectarian terms, Saudi Arabia has repeatedly accused Iran of fuelling sectarianism by backing Shia militias who have targeted Sunnis in Iraq, Yemen, Lebanon and Syria (Saudi Arabia could, 2016). A Carnegie Endowment for International Peace study concluded however that anti-Shia rhetoric was much more common online than anti-Sunni rhetoric (Siegel, 2015).

Saudi Arabia had legitimate concerns in the immediate wake of the Iranian revolution. The fall of the autocratic pro-US regime of the Shah made place for a regime that 
was revolutionary and keen on exporting its revolution to the Gulf. Iran made no bones about it. It took however less than a year for nationalism to trump revolution in Iran. The process was accelerated by the Saudi-backed Iraqi invasion of Iran and the eight year-long Iran-Iraq war. From Iraq's formal declaration of war on 22 September 1980 to Iran's acceptance of a ceasefire on 20 July 1988, at least half a million and possibly twice as many troops were killed on both sides, at least half a million became permanent invalids, some 228 billion dollars were directly expended and more than $\$ 400$ billion of damage, mostly to oil facilities, but also to cities, was inflicted (Razoux, 2015).

The Saudi determination to counter the Iranian revolutionary threat by defeating rather than containing it has ever since shaped Saudi policy towards Iran and Shia Muslims despite the occasional thaw in relations. Iran has repeatedly taken the bait with the creation of Hezbollah, political protests during the hajj in Mecca, the 1996 bombing of the Khobar Towers in Saudi Arabia, to name just a handful of incidents.

Nonetheless, the kingdom's handling of relations with Iran was certain to ultimately backfire and position the Islamic republic as an existential threat. Rather than embrace its Shia minority by ensuring that its members had equal opportunity and a stake in society, while countering discriminatory statements by the clergy and government institutions, the kingdom grew even more suspicious of Shias who populate the country's oil-rich eastern province. In doing so, they provided Iran with a golden opportunity to forge closer ties with disgruntled Shia communities in the Gulf. Middle East expert Suzanne Maloney predicted that "the most important variable in the stability of states with significant Shia minorities - such as Bahrain, Saudi Arabia, Kuwait, and Pakistan? will be the overall tenor of these states' domestic politics, particularly on minority rights issues" (Maloney, 2008: 48).

A Kuwaiti Shiite businessman who visited Tehran shortly after the 1979 toppling of the Shah saw the revolution as opening the door to a new era. "We are citizens of $\mathrm{Ku}$ wait, Bahrain, Saudi Arabia. We are Shiites, not Iranians. What happened in Iran is good for everyone. It will persuade our governments to treat us as equals," the businessman said at the time (Dorsey, 1979). The businessman's words went unheeded.

Instead of acknowledging legitimate grievances, the Al Sauds relied on repression at home and on autocratic minority Sunni leaders in Iraq and Bahrain to keep a grip on majority Shia populations. ?Saudi leaders failed to recognise that Tehran's perception of itself as Shia Central was no less legitimate than Riyadh's insistence on being Sunni Central or Israel's claim that it is the centre of the Jewish world. They also consistently ignored the fact that it was hundreds of thousands of Iraqi Shia Muslims who died in the Iran-Iraq war defending their country against their Iranian Shia brethren (Razoux, 2015).

Saudi concern about Iran has further been fuelled by changing US attitudes towards the Middle East and North Africa in general and Saudi Arabia in particular. US officials for much of their country's relationship with Saudi Arabia have insisted that the two countries do not share common values, only common interests. Underlying increasingly cooler relations between Washington and Riyadh is the fact that those interests are diverging. The divergence first became public after the 2003 US invasion of Iraq that brought the Shiite majority for the first time to power. The invasion left the Saudis incredulous. "To us, it seems out of this world that you do this. We fought a war together 
to keep Iran from occupying Iraq after Iraq was driven out of Kuwait (in 1991). Now we are handing the whole country over to Iran without reason," Saudi Foreign. Minister Prince Saud al Faisal told an American audience in 2005 (Al-Faisal, 2005).

The divergence became even more evident with the eruption of popular revolts in 2011 and particularly US criticism of the Saudi military intervention in Bahrain to squash a rebellion and initially hesitant American support for the toppling of Egyptian President Hosni Mubarak. It was also obvious in US persistence in reaching a nuclear agreement with Iran that is returning the Islamic republic to the international fold despite deep-felt Saudi objections.

The result of all of this has been with the rise in 2015 of the Salmans, King Salman and his powerful son, deputy crown prince Mohammed bin Salman a far more assertive foreign and military policy. Saudi Arabia's new assertiveness was however not a declaration of independence from the United States. On the contrary, Mohammed Bin Salman made that very clear in an Economist interview. It was designed to force the United States to reengage in the Middle East in the belief that it would constitute a return to the status quo ante: unconditional US support for the kingdom in the belief that it is the best guarantor for regional stability.

The problem with that assumption was that history is not static; it is a dynamic process of continuous change. The US attitude of uncritically shared common interests with Saudi Arabia had evolved. In a meeting with Australian prime minister Malcolm Turnbull on the side lines of the 2013 Asia Pacific Economic Cooperation (APEC) summit in Bali, Obama blamed Saudi Arabia for Indonesia's gradual move away from its relaxed, syncretic form of Islam to a more unforgiving, ultra-conservative interpretation. "Today, Islam in Indonesia is much more Arab in orientation than it was when we lived there," Obama said, harking back to his childhood years in the country. When Turnbull asked whether the Saudis were not friends of the United States, Obama responded: "It's complicated" (Goldberg, 2016).

In a series of interviews with B. Obama and his closest associates, journalist Jeffrey Goldberg noted to the president that he was less likely than previous presidents to axiomatically side with Saudi Arabia in its dispute with its arch rival, Iran. B. Obama didn't disagree: "Iran, since 1979, has been an enemy of the United States, and has engaged in state-sponsored terrorism, is a genuine threat to Israel and many of our allies, and engages in all kinds of destructive behaviour. And my view has never been that we should throw our traditional allies (the Saudis) overboard in favour of Iran" (ibid.).

The president, however, went on to say that the Saudis needed to "share" the Middle East with their Iranian foes. "The competition between the Saudis and the Iranians - which has helped to feed proxy wars and chaos in Syria and Iraq and Yemen - requires us to say to our friends as well as to the Iranians that they need to find an effective way to share the neighbourhood and institute some sort of cold peace. An approach that said to our friends 'You are right, Iran is the source of all problems, and we will support you in dealing with Iran' would essentially mean that as these sectarian conflicts continue to rage and our Gulf partners, our traditional friends, do not have the ability to put out the flames on their own or decisively win on their own, and would mean that we have to start coming in and using our military power to settle scores. And that would be in the interest neither of the United States nor of the Middle East," Obama said (ibid.). 
The Al Sauds were quick to respond to Obama's suggestion that Saud Arabia and other US allies were free riders, happy to let the United States do the heavy lifting when necessary. "No, Mr. Obama. We are not free riders," said Prince Turki Al-Faisal, a former head of Saudi intelligence, who also served as the kingdom's ambassador to the United States and Britain. Al-Faisal listed a litany of ways Saudi Arabia had helped the US, including providing intelligence on planned jihadist attacks; training and funding of anti-Assad rebels; offering to send ground troops to Syria; and being the largest funder of efforts to help refugees from the Middle East, the sole financier of the United Nations Counter-terrorism Center, and a buyer of US treasury bonds despite their low yield. "No, Mr. Obama. We are not the 'free riders' that to whom you refer. We lead from the front and we accept our mistakes and rectify them. We will continue to hold the American people as our ally and don't forget that when the chips were down, and George Herbert Walker Bush sent American soldiers to repel with our troops Saddam's aggression against Kuwait, soldiers stood shoulder to shoulder with soldiers. Mr. Obama, that is who we are," Al Faisal said (Al-Faisal, 2016).

\section{BENT ON PROVOCATION}

The perceived Iranian threat prompted Saudi Prince Bandar bin Sultan, for decades a key player in the shaping of Saudi security policy and the kingdom's relations with the United States, to warn Richard Dearlove, the head of the British Secret Intelligence Service, MI6, already more than a decade ago that: "the time is not far off in the Middle East, Richard, when it will be literally 'God help the Shia'. More than a billion Sunnis have simply had enough of them" (Cockburn, 2014). More recently, in October 2015, Saudi TV Host Abdulellah Al-Dosari celebrated unchallenged the death of some 400 Shiite Iranians, including Iranian diplomats, in a stampede during the haj in Mecca: "Praised be to Allah, who relieved Islam and the Muslims from their evil. We pray that Allah will usher them into hell for all eternities" (Saudi TV, 2015).

This Saudi approach has sown the seeds for intermittent domestic unrest and repeated Saudi and Iranian tit-for-tat attempts to weaken and undermine the legitimacy of the other, set the stage for a Saudi global effort to ensure that Muslim communities across the globe empathise with Wahhabism rather than revolutionary Iranian ideals, and the further poisoning of relations between the two regional powers.

The poisoning was evident in the will of Ayatollah Ruhollah Khomeini, whose anti-monarchical views were rooted in the oppression of the imperial regime of the shah that he had toppled. "Muslims should curse tyrants, including the Saudi royal family, these traitors to God's great shrine, may God's curses and that of his prophets and angels be upon them," Khomeini ordained (Moin, 2015).

Saudi Arabia greeted 2016 with the execution in one day of 47 people. It was the biggest mass execution Saudi Arabia since the 1980 killing of 63 jihadist rebels who seized Mecca's Grand Mosque in 1979. The condemned were largely convicted of leading or carrying out Al Qaeda attacks in Saudi Arabia, but included Shiites accused of attacks on police since the 2011 popular Arab revolts. Among the executed was prominent Saudi Shi'ite cleric Nimr al-Nimr (Saudi Arbia says, 2016). Al-Nimr and six other 
Saudi Shias, including his nephew Ali who was not among those executed, were sentenced to have their bodies put on public display after execution in the most severe penalty available to Saudi judges (Saudi Arabia to Sue, 2015).

The fallout constituted a throwback to 2011 when Saudi Arabia was shell shocked as it became evident that the majority of the $9 / 11$ perpetrators were Saudi nationals. Saudi society was at the time put by intelligence agencies and the international media under the kind of scrutiny the kingdom had never experienced before. The same happened again in the wake of the execution of Al Nimr. The Saudis expected human rights criticism. The criticism traditionally went into one ear and out the other. What the Saudis didn't expect was that the international focus fuelled by the emergence of IS would increasingly be on Wahhabism and Salafism itself. Mohammed Bin Salman summed up the Al Saud's dilemma when he told "The New York Times" in November 2015: "The terrorists are telling me that I am not a Muslim. And the world is telling me I am a terrorist" (Friedman, 2015).

The Saudi justice ministry, in an indication that the kingdom viewed scrutiny of the kingdom and its potential communalities with IS as a threat, warned that it would initiate legal action against those who compared the kingdom to IS on Twitter, starting with an unidentified tweeter who described the sentencing to death of prominent Saudi-born Palestinian poet Ashraf Fayadh on charges of apostasy as "IS-like". A justice ministry official cautioned that "questioning the fairness of the courts is to question the justice of the Kingdom and its judicial system based on Islamic law, which guarantees rights and ensures human dignity" (Saudi Arabia to Sue, 2015).

Al-Nimr's execution was not simply designed to send a message to domestic opposition, nor was it simply intended to send a message to Iran. The message, 'don't mess with me,' had long been loud and clear. The execution was part of a deliberate, failed strategy to delay, if not derail, implementation of the nuclear agreement and Iran's return to the international fold. Iranian hardliners played into Saudi hands with the storming of the Saudi embassy and Saudi Arabia's subsequent breaking off of diplomatic and economic relations with Iran (Chulov, 2016). The Saudi moves were designed to strengthen hardliners in advance of February 2016's elections in Iran for parliament and the Assembly of Experts, the council that eventually will elect Iran's next spiritual leader (Iran Elections, 2016).

The strategy made - and still makes - perfect sense. Saudi regional leadership amounts to exploitation of a temporary window of opportunity for regional hegemony rather than reliance on the assets and power needed to sustain it long-term. Saudi Arabia's interest is to extend its window of opportunity for as long as possible. That window of opportunity exists as long as the obvious regional powers - Iran, Turkey and Egypt - are in various degrees of disrepair. Punitive international sanctions and international isolation long stymied Iran in claiming its position as regional hegemon. And that is what is changing. Iran may not be Arab and maintains a sense of Persian superiority, but it has the assets for long-term regional hegemony that Saud Arabia lacks: a large population base, an industrial base, resources, a battle hardened military, a deep-rooted culture, a history of empire and a geography that makes it a crossroads. Saudi Arabia's control of Mecca and money will not allow it to successfully compete, at least not with Wahhabism in control. 


\section{OUTMODED IDEOLOGY}

As a result, the Al Sauds are inching ever closer to a fundamental change in their relationship with the Wahhabis. Reform that enables the kingdom to become a competitive, $21^{\text {st }}$ century knowledge economy is difficult, if not impossible, as long as it is held back by the strictures of a religious doctrine that looks backwards rather than forwards, which idealises life as it was at the time of the prophet and his companions.

Saudi reform is further hampered by the Al Sauds continued insistence on the principle of "progress without change," the slogan adopted by the government in the 1990s (Pollock, 2016), to adjust to changing regional, economic, political and social changes. The principle implied that the building blocks of the A1 Saud's grip on power - a social contract that promised cradle-to-grave welfare in exchange for a surrender of political rights; its pact with the clergy, and repression - were immutable.

That could change as Saudi Arabia appears to be caught in a perfect storm. Arab popular protests in 2011 toppled the leaders of Tunisia, Egypt, Libya and Yemen; sparked a brutal civil war in Syria and Saudi military interventions in Bahrain and Yemen; and a divergence of interests between the kingdom and the United States, its main protector. Traditional autocratic rule in the Middle East and North Africa is being challenged like never before.

Tumbling commodity and energy prices are forcing the Saudi government to reform, diversify, streamline and rationalize the kingdom's economy. The government is cutting subsidies, raising prices for services, searching for alternative sources of revenue, and moving towards a greater role for the private sector and women. Cost cutting occurs at a time that Saudi Arabia is spending effusively on efforts to counter winds of political change in the region with its stalled military intervention in Yemen, its support for anti-Bashar al Assad rebels in Syria, and massive financial injections into an increasingly troubled regime in Egypt that has yet to perform.

Wahhabism was Saudi Arabia's defence against the Islamic revolution that demonstrated that rulers can be toppled, that raised questions about a clergy that slavishly served the needs of an autocratic ruler and that recognised some degree of popular sovereignty. To be sure, Wahhabism has been an expansionary, proselytising force from its inception (De Koning, 2014: 33). But the success of an Islamic revolution that could potentially inspire not only Shias but also Sunnis persuaded the Al Sauds, flush with oil dollars in the wake of the 1973 oil crisis, to kick Wahhabi proselytization into high gear.

It may be hard to conceive of Wahhabism as soft power, but that was the Saudi government's goal in launching the single largest dedicated public diplomacy campaign in history to establish Wahhabism and Salafism as a major force in the Muslim world, capable of resisting any appeal Iran might have. Estimates of Saudi expenditure on this campaign in the almost four decades since the Iranian revolution range from $\$ 75$ to \$100 billion (Bin Talal, 2015; Kaplan, 2003).

\section{COUNTING THE COST}

The cost, however, may be becoming too high. Saudi Arabia finds itself being increasingly compared to IS. Not unfairly. Wahhabism at the beginning of the $20^{\text {th }}$ cen- 
tury and the creation in 1932 of the second Saudi state was what IS is today. Saudi Arabia is what IS will become should it survive. Despite their denunciations of IS as a deviation from Islam, Saudi clerics admit this.

Adel Kalbani, a former imam of the Grand Mosque in Mecca was unequivocal. "Daesh (the Arabic reference to IS) has adopted Salafist thought. It's not the Muslim Brotherhood's thought, Qutubism, Sufism of Ash' ari thought. They draw their thoughts from what is written in our own books, from our own principles... The ideological origin is Salafism. They exploited our own principles that can be found in our own books... We follow the same thought but apply it in a refined way," Kalbani said (Integrity UK, 2016).

One can question the effectiveness of the Saudi soft power effort on multiple levels. True, the Organisation of Islamic Cooperation (OIC) in January 2016 backed Saudi Arabia in its conflict with the Islamic republic (Final Communiqué, 2016). But only four countries broke off diplomatic relations with Iran following the storming of the Saudi embassy in Riyadh. All four - Bahrain, Djibouti, Sudan and Somalia - are dependent on the kingdom. None of the other Gulf states did so, although some lowered the level of their diplomatic representation in Tehran. Djibouti was rewarded with a Saudi decision to establish a military base in the country in the Horn of Africa that already hosts US, French, Japanese and Chinese military facilities (Toumi, 2016). The announcement came barely a year after Saudi Arabia declared Djibouti's foreign minister, Mahamoud Ali Youssouf, persona non grata, the United Arab Emirates closed its consulate in the country, and a contingent of Gulf Cooperation Council (GCC) troops was forced to leave the African country (Saudi Arabia Declares, 2015). Saudi Arabia pledged $\$ 50$ million in aid to Somalia on the day the violence-wracked country announced that it was breaking off diplomatic relations with Iran (Somalia received, 2016).

The Sudanese decision was likely to impact Iran the most given that Sudanese ports were frequently staging areas for Iranian weapons shipments to the Middle East and Africa (Rosen, 2016). Sudan had earlier signalled Saudi Arabia that it may be willing to switch sides with the closure in September 2014 of Iranian cultural centres in the capital Khartoum and elsewhere in the country because they were spreading Shiism (Sudan shuts down, 2014). The closures came six months after Saudi Arabia ordered its banks to stop doing business with their Sudanese counterparts, a move that hurt Sudanese workers in the kingdom who were sending remittances home (Sudan Isolation, 2014).

Saudia Arabia's relatively poor soft power return on investment is not simply that Muslim states largely want to keep their lines open to two of the Middle East's foremost power. It also is the result of domestic repercussions that governments across the Muslim world fear. Saudi Arabia was taken aback when Pakistan despite massive Saudi financial support for its economy, madrassas, and nuclear program and the kingdom's assistance in getting Prime Minister Nawaz Sharif out of prison following General Pervez Musharraf's 1999 coup and hosting him for his seven years in exile; rejected in 2015 a Saudi request that it support military intervention in Yemen.

Saudi Arabia had assumed that it had sufficient Pakistani chits to cash in. The kingdom is home to over two million Pakistani expatriates (Kakar, 2015) and is Pakistan's single largest source of remittances (State Bank of Pakistan). In times of difficulty, 
Saudi Arabia has come to Pakistan's aid - for example, by providing oil on deferred payment when Islamabad was hit by U.S. sanctions after conducting nuclear tests in 1998. In addition, some 1,200 Pakistani troops are stationed in the kingdom (Anis, 2016). Pakistani military foundations recruited retired military personnel to serve as mercenaries in Bahrain during the Saudi-backed crushing of a popular revolt in Bahrain in 2011 (Racine, 2016).

Yet, with Shiites constituting up to 20 percent of the population and escalating sectarian tensions in recent years and plans for closer economic and energy cooperation with Iran, Pakistan has little choice but to walk a tightrope. Just how tight the tightrope is, was evident in guidelines for coverage of the Saudi-Iranian dispute issued by Pakistan's electronic media regulatory authority. "Media houses should ideally refrain from airing programs that can result in irreparable damage," the guidelines said (Haider, 2016).

The balance of power in the Saudi soft power strategy between recipients of Saudi largesse and the kingdom seemed evident when Saudi Arabia in March 2016 rewarded Pakistani reluctance to uncritically back Saudi policy with $\$ 122$ million in financial and economic assistance, the highest amount officially given to Pakistan in the last five years (Saudi extends, 2016).

\section{KNEEJERK REACTIONS}

Pakistan was not the only major Muslim nation in which check book diplomacy failed to elicit the kind of results Saudi Arabia had hoped for. Various Muslim nations, including Malaysia, Lebanon (Nader, 2015) and Indonesia were quick to state that they had not been consulted and had yet to decide whether they would participate when Saudi Arabia in December 2015 hastily announced the creation of a 34-nation, Sunni Muslim anti-terrorism military command to be headquartered in Riyadh. Malaysian Defence Minister Hishammuddin Hussein ruled out any military contribution to the command ('Members'surpriced, 2015). So did senior Bangladeshi officials. Widespread scepticism did not prevent many of these countries from participating in a 20-nation military exercise in the kingdom in March 2016.

The alliance, despite the participation of various sceptics in the exercise, was however likely to be paralyzed by among other things disagreements over what constituted terrorism given that various of its potential members were likely to take issue with Saudi Arabia's inclusion of everything ranging from adherence to atheism to the vaguest contact with any group deemed hostile to the kingdom (Saudi Arabia: New Terrorism, 2014). Complicating the question of what qualifies as terrorism was the fact that the kingdom rejected the notion of much of contemporary political violence being jihadi in nature on the grounds that it was not a feature of Islam.

The announcement of the command and the exercise constituted both the kingdom's response to the mounting chorus of criticism of Wahhabism and comparisons between the kingdom and IS and US pressure on Saudi Arabia and other Gulf states to step up their contributions to the anti-IS coalition (Demirjian, 2015). As a result, Saudi Arabia projected the alliance as evidence of its key role in the struggle against jihadism as well 
as of the assertion that jihadism and Wahhabism were locked into an epic battle over who represents true Islam.

"A closer look at Isis reveals that it is engaged in an entrenched theological war with the Saudi religious establishment to determine who justifiably espouses the purest tenets of Sunni Islam. As the custodian of the two holy mosques in Mecca and Medina and the host of the world's Muslims for the pilgrimage, Saudi Arabia leads one and a half billion Muslims in fighting Isis. The kingdom's leadership of the recently announced Muslim coalition to fight terrorism in all its forms confirms that Saudi Arabia is not only not the source of Isis but it is the terrorist group's central opponent and the only nation that can fully and legitimately defeat it once and for all," said Nawaf Obaid, a Saudi policy analyst with close ties to the government who is widely believed to reflect Mohammed bin Salman's thinking (Obaid, 2015a).

The announcement of the alliance and the exercise were indications that Saudi Arabia believed that relying for decades on a well-funded proselytization program to globally enhance its soft power and position itself as the foremost power in the Arab and Muslim worlds, was no longer sufficient. Propagation of Wahhabism was designed to cement Saudi Arabia's position as a key US and Western ally and ensure that survival of the Al Sauds would continue to be viewed as a crucial American and European national interest. US responses to the 2011 popular Arab revolts, the subsequent US-led nuclear agreement with Iran that brought the Islamic republic in from the cold, fears that the US was seeking to disengage from the Middle East, and potential shifts in energy markets away from the Middle East as a result of technological advances undermined the fundamental assumptions of Saudi foreign and defense policy.

According to N. Obaid: "First, the Saudis and their allies have come to realize they must solve their own problems in the face of Western withdrawal. Second, they know they need to counter Iran's destabilizing regional actions being carried out in the name of an absurd revolutionary agenda. Finally, it is clear they must take on the terrorist groups and unstable states that are preventing peace and prosperity from taking root in the Middle East... To bolster the security of neighbouring states, power projection missions to demonstrate real military might will be necessary, and succeeding in these efforts is another tenet of this new Saudi Defense Doctrine. As the threats to the region increase, those missions are likely to become larger and more complicated" (Obaid, 2015b).

As a result, Saudi Arabia has begun to assert itself politically, diplomatically and militarily in a series of moves that were designed to create Muslim alliances and security networks with the kingdom as the focal point. Saudi Arabia's first move was in 2013 to reject a highly coveted, non-permanent seat on the United Nations Security Council (Worth, 2013). The Saudi rejection was an expression of frustration with UN impotence in Syria as a result of Russia and China wielding their veto power to protect the Assad regime and perceptions that the United States was shirking its responsibilities in Syria.

It was also a move that allowed the kingdom to chart an independent, more activist foreign and military policy, particularly regarding support for Syrian rebels and Saudi efforts protect its interests in Yemen, uninhibited by the confines of a seat on the Security Council. Saudi efforts culminated in the kingdom's announcement of the predomi- 
nantly Muslim military alliance. Fahad Nazer, a former political analyst for the Saudi embassy in Washington, held out the possibility that Saudi Arabia may be seeking to create an Islamic NATO (Nazer, 2015). Although senior Saudi officials have suggested that the Islamic coalition was intended to compliment the US-led effort against IS, Nazer argued that "the notion that it may be intended to supplant it should be given consideration" (ibid.).

\section{PYRRHIC VICTORY}

On the level of Muslim communities and at the level of Saudi relations with a host of government agencies in Muslim countries, the kingdom's soft power strategy has paid off. It is proving however to be increasingly a pyrrhic victory. Societies, particularly in countries with governments that play politics with religion, have become more conservative. The result is greater intolerance towards minorities and greater social volatility.

The payback is obvious: take the example of $\mathrm{H}$. Asad Said Ali, a soft-spoken, mild mannered retired Indonesian intelligence chief, who spent 12 years as an operative in Saudi Arabia and Syria, and later served as deputy head of Nahdlatul Ulema (NU), a traditionalist Indonesian Sunni movement that with some 50 million followers is the world's largest independent Muslim organization. Said Ali embodies the tension between the inroads Saudi Wahhabi thinking has made within the Indonesian security and defense establishment and the desire to maintain the country's adherence to a culture of tolerant and pluralistic Islam.

Sitting in a spacious office furnished with leather sofas in an upmarket Jakarta neighbourhood that is home to embassies and luxury hotels, Said Ali, who retired in 2010 as deputy head of intelligence, describes NU's efforts to fend off Wahhabi and Salafi attempts to take over NU mosques. When Salafis visited an NU mosque in the Jakarta district of Kenayoran and advised the local imam that they would be returning with 40 people to take over his mosque in a week's time and that he could best pack his bags before then, Said Ali sent a $100 \mathrm{NU}$ members to make sure that the place of worship remained in his group's hands. "They infiltrate our mosques. If we give them too much freedom, they grab our mosques," he said (Dorsey, 2016b).

Yet, on balance, weeks after IS claimed responsibility for an attack on a police station and a Starbucks in January 2016 in Jakarta's central business district, Said Ali, echoing Wahhabi rejection of Shiism and Saudi allegations of Iranian interference in the affairs of other countries, asserted that Indonesia's 4 million Shias who account for $1.6 \%$ of the population posed a greater national security threat than Wahhabis or Salafis. "The problem is that the Shiites are backed by Iran. They want to replace governments with Iranian-style Islamic republics. The Shiites are more dangerous because they are very active. Some two million Indonesians have converted to Shiism since the Iranian revolution in 1979. Shiite institutions in Indonesia grow by ten percent a year. The Iranians endanger our society. The Saudis don't. The Iranians are better organized than the Saudis. The Saudis, the Salafis are open about who they are. The Iranians and the Shiites practice taqiyya," a Shiite legal dispensation that allows individual or groups to dissimulate and deny their faith if they fear or risk persecution, S. Ali said. 
The author of numerous books, Said Ali fetched a pink pamphlet containing the speech of a Shiite cleric. In his opinion: "I' $m$ collecting the speeches of Khomeini and others to prepare recommendations for the government on how to deal with the Shiites. The issue is freedom of religion versus political motives that threaten our national security. We have to limit the Shiite movement politically. Like the Wahhabis, we have to ensure that they do not advance to senior positions in the military."

A staunch believer in Indonesian Islam that is rooted in the country's multicultural history - Said Ali - who engages with Saudi officials and Wahhabi clerics, defended Indonesian practices like the honouring of the dead and the celebration of the Prophet Mohammed's birthday against criticism by Wahhabis and Salafis who view anything but the worship of Allah as idolatry. According to S. Ali: "People refuse Wahhabi prescripts even if they take Saudi money. We are middle of the road. We don't rely on radical teaching. We use our brains and adhere to tradition. Fact is however that we can confront the Wahhabis with dialogue. Dialogue with Shiites is impossible because of taqiyya. We cannot trust them." He argued that Indonesian culture is strong enough to limit the impact of Saudi-style Wahhabism and Salafism that preaches obedience to the ruler and shies away from politics despite the fact that it has contributed to greater Indonesian intolerance towards minorities and has spawned jihadist groups like Jemaah Islamiya that was responsible for the 2002 and 2005 Bali bombings as well as attacks on hotels and the Australian embassy in Jakarta, and IS. "Pure Wahhabism is not a problem. It's not political. Look at Saudi Arabia, they don't have political parties," he said. Yet, Indonesia has only lax controls over what happens with Saudi funds entering the country often ferried in suitcases through airports and ports. "Customs looks the other way," asserting that while the government has no estimate about how much Saudi money is brought into the country, the amount dwarfs that being invested by Iran in the spreading of its revolutionary ideology.

Saudi inroads into the intelligence and other government agencies of majority Muslim nations in Asia was further highlighted when the Indonesian and Malaysian defence ministers travelled together to the kingdom within 48 hours of the IS attacks in Jakarta 2016. Malaysian defense minister Hussein said the two officials had benefited during their visit from Saudi Arabia's experience in fighting IS (Khairul, 2016). "Our grassroots are impatient. They hear the daily denunciations of NU by the Wahhabis. That is our problem with the Wahhabis," Said Ali said, yet insisting in the same breath that the Shiite threat was mushrooming. "It filters through generations even if the son of a Shiite is only half Shiite because of marriage and his son is a quarter Shiite. It progresses," he said.

Similarly, Wahhabi influence in Indonesian education emerged when activists revealed that a government-issued school book portrayed Ibn Abdul Wahhab as one of the Muslim world's most influential thinkers even though it took almost 200 years and the $\mathrm{Al}$ Saud's largesse to ensure that his puritan views gained global currency. "The Wahhabis have manged to deploy their people throughout bureaucratic institutions and universities," said Alissa Wahid, the activist daughter of former Indonesian president Abdurrahman Wahid. "Much like, Malaysia, minorities, including Shiites; Ahmadis, a sect viewed by orthodox Muslims as heretics; Christians; and indigenous groups of syncretic Muslims find themselves increasingly on the defensive against efforts to 
marginalize them. The indigenous risk being forced to no longer publicly identify themselves as Muslims. The Ahmadis are being banned from building mosques or reading the Qur'an in public," Wahid said (Dorsey, 2016c).

The potentially increasing cost to the Saudi state and the Al Sauds was evident when two major political parties in the Dutch parliament recently the government whether there was a legal basis for outlawing Wahhabi and Salafi institutions, schools, academies or social services that are funded by Saudi and Kuwaiti institutions. The government advised in February 2016 that it was not considering the banning of Wahhabi and Salafi organizations (Groen, 2016). Nevertheless, the Dutch debate lifted the veil on the risk involved in the association of Wahhabism and Salafism with jihadism that could at the least lead to bans on foreign funding and the potential expulsion of Saudi religious attaches attached to the kingdom's embassies across the globe.

That risk was also obvious when German vice-chancellor Sigmar Gabriel, in a rare attack on Saudi Arabia by a senior Western government official while in office, accused the kingdom of financing extremist mosques and communities in the West that constitute a security risk and warned that it must stop. "We have to make clear to the Saudis that the time of looking away is over. Wahhabi mosques all over the world are financed by Saudi Arabia. Many Islamists who are a threat to public safety come from these communities in Germany," he said (German Vice Chancellor, 2015). A report by the German intelligence service, Bundesverfassungsschutz, concluded that 547 of the 677 Germans who had travelled to Syria to join jihadist groups up until June 2015 emanated from a Salafi milieu (Analyse der, 2016).

The German report reflected changing international attitudes towards Saudi sectarianism and the fighting of proxy wars against Iran. Western intelligence and policy circles had quietly concluded that the crisis in Syria was in part a product of the international community's indulgence of Saudi propagation of Wahhabism. Central Intelligence Agency (CIA) director John Brennan unsuccessfully tried in 2011 as peaceful anti-regime protests in Syria descended into violence to persuade Saudi Arabia at a meeting in Washington of Middle Eastern intelligence chiefs to stop supporting militant Sunni Muslim Islamist fighters in Syria. ?An advisor to the Joint Chiefs of Staff recounted that the Saudis ignored Brennan's request. They "went back home and increased their efforts with the extremists and asked us for more technical support. And we say $\mathrm{OK}$, and so it turns out that we end up reinforcing the extremists," the advisor said (Hersh, 2016).

$$
* * *
$$

In sum, the complex relationship between the A1-Sauds and Wahhabism creates policy dilemmas for the Saudi government on multiple levels and complicates its relationship with the United States and its approach towards the multiple crises in the Middle East and North Africa, including Syria, IS and Yemen.

The Al Sauds problems are multiplied by the fact that Saudi Arabia's clergy is tying itself into knots as a result of its sell-out to the regime and its close ideological affinity to more militant strands of Islam. Dissident Saudi scholar Madawi Al-Rasheed argues that the sectarianism that underwrites the anti-Iran campaign strengthens regime stabil- 
ity in the immediate term because it ensures "a divided society that is incapable of developing broad, grassroots solidarities to demand political reform... The divisions are enhanced by the regime's promotion of an all-encompassing religious nationalism, anchored in Wahhabi teachings, which tend to be intolerant of religious diversity... Dissidence, therefore, centres on narrow regional, tribal and sectarian issues" (Al-Rasheed, 2016).

Historian Richard Bulliet argued that Saudi "King Salman faces a difficult choice. Does he do what President Obama, Hillary Clinton and many Republican presidential hopefuls want him to do, namely, lead a Sunni alliance against the Islamic State? Or does he continue to ignore Syria, attack Shias in Yemen and allow his subjects to volunteer money and lives to the IS caliph's war against Shia? The former option risks intensifying unrest, possibly fatal unrest, in the Saudi kingdom. The latter contributes to a growing sense in the West that Saudi Arabia is insensitive to the crimes being carried out around the world in the name of Sunni Islam. Prediction: in five years' time, Saudi Arabia will either help defeat the Islamic State, or become it."

Whether Bulliet is right or not in his prediction, Wahhabism is not what's going to win Saudi Arabia lasting regional hegemony in the Middle East and North Africa. In fact, as long as Wahhabism is a dominant player in the kingdom, Saudi Arabia is even less likely to win its battle for hegemony. At the end of the day, it is a perfect storm. The stakes for Saudi Arabia are existential and the kingdom may well be caught in a Catch-22.

Iran poses an existential threat, not because it's still projects itself as a revolutionary state, but simply by what it is, the assets it can bring to bear and the intrinsic challenge it poses. But equally existential is the fact that Wahhabism is likely to increasingly become a domestic and external liability for the Al Sauds. Their future is clouded in uncertainty, no more so if and when they lose Wahhabism as the basis for the legitimacy of their absolute rule.

\section{BIBLIOGRAPHY}

Al-Faisal S. (2005), The Fight Against Extremism and the Search for Peace, "Council of Foreign Relations", 25.09.2005, www.cfr.org/publication/8908/fight-against-extremism_and the_search for_peace_rush transcript federal_news_service_inc.htlml (23.11.2005).

Al-Faisal T. (2016), Mr Obama, we are not 'free riders', "Arab News", 13.03.2016, http://www.arabnews.com/columns/news/894826 (21.03.2016).

Al-Rasheed M. (2016), Saudi regime resilience after the 2011 Arab popular uprisings, "Contemporary Arab Affairs", Vol. 9, No. 1.

Analyse der Radikalisierungshintergründe und-verläufe der Personen, die aus islamistischer Motivation aus Deutschland in Richtung Syrien oder Irak ausgereist sind, Bundesverfassungsschutz, 02.2016, Berlin.

1 R. Bulliet (2015), King Salman's dilemma, “Agence Global", 23.11.2015, http://www.agenceglobal.com/index.php?show=article\&Tid=2914 (23.01.2016). 
Anis M. (2016), 1,I80 Pakistan Army personnel present in Saudi Arabia: Kh Asif, "The News", 20.01.2016, http://www.thenews.com.pk/print/92465-1180-Pakistan-Army-personnel-presentin-Saudi-Arabia-Kh-Asif (23.01.2016).

Baer R. (2003), Sleeping with the Devil: How Washington Sold Our Soul for Saudi Crude, Kindle edition, New York.

Bin Talal G.b.T. (2015), What Hs Broken? Political, Sociological, Cultural and Religious Changes in the Middle East over the Last 25 Years, S. R. Nathan Annual Distinguished Lecture, "Middle East Institute", 17.03.2015, https://mei.nus.edu.sg/themes/site themes/agile_records/images/uploads/What_has_broken_v.8,_As_Given, 14.11.15.pdf (23.04.2015).

Chulov M. (2016), Saudi Arabia cuts diplomatic ties with Iran after execution of cleric, "The Guardian", 4.01.2016, http://www.theguardian.com/world/2016/jan/03/saudi-arabia-cuts-diplomaticties-with-iran-after-nimr-execution (23.01.2016).

Cockburn P. (2014), Iraq crisis: How Saudi Arabia helped Isis take over the north of the country, "The Independent", 13.07.2014, http:/www.independent.co.uk/voices/comment/iraq-crisis-howsaudi-arabia-helped-isis-take-over-the-north-of-the-country-9602312.html (13.07.2014).

Commins D. (2009), The Wahhabi Mission and Saudi Arabia, London: Kindle edition.

Country-wise Workers'Remittances, State Bank of Pakistan, http://www.sbp.org.pk/ecodata/Homeremit.pdf (23.01.2016).

De Koning M., Wagemakers J., Becker C. (2014), Salafisme, Amsterdam.

Demirjian K. (2015), Carter promises helicopters for Iraq, tells Gulf countries to "step up" in the fight against ISIS, "The Washington Post", 9.12.2015, https://www.washingtonpost.com/ news/powerpost/wp/2015/12/09/carter-promises-helicopters-for-iraq-tells-gulf-countries-tostep-up-in-the-fight-against-isis/ (23.01.2016).

Dorsey J. M. (2016a), Creating Frankenstein: The Saudi export of Wahhabism, "The Straits Times", 13.03.2016, http://www.straitstimes.com/opinion/creating-frankenstein-the-saudi-export-ofwahhabism (13.03.2016).

Dorsey J. M. (2016b), Interview with the author, 01.02.2016.

Dorsey J. M. (2016c), Interview with the author, 01.02.2016.

Dorsey J. M. (1979), Interview with the author, 12.04.1979.

Final Communiqué of The Extraordinary Meeting of The Council of Foreign Ministers of The Organization Of Islamic Cooperation on Aggressions on The Embassy of The Kingdom of Saudi Arabia in Tehran and Its Consulate General In Mashhad, Organization of Islamic Cooperation, 22.01.2016, http://www.oic-oci.org/oicv2/topic/?t_id=10837\&t_ref=4262\&lan=en (23.01.2016).

Former Imam of the Grand Mosque in Mecca, Adel Kalbani: Daesh ISIS have the same beliefs as we do (2016), Integrity UK, 27.01.2016, https:/www.youtube.com/watch? $\mathrm{v}=$ GWORE6OBfhc (28.01.2016).

Friedman T. (2015), Letter from Saudi Arabia, "The New York Times", 25.11.2015, http://www.nytimes.com/2015/11/25/opinion/letter-from-saudi-arabia.html (23.01.2016).

German Vice Chancellor warns Saudi Arabia over Islamist funding (2015), Reuters, 6.12.2015, $\mathrm{http} / / /$ www.reuters.com/article/us-saudi-germany-idUSKBN0TP0H720151206 (23.01.2016).

Goldberg J. (2016), The Obama Doctrine, The U.S. president talks through his hardest decisions about America's role in the world, "The Atlantic", 04.2016, http://www.theatlantic.com/magazine/archive/2016/04/the-obama-doctrine/471525/ (2.05.2016).

Groen J. (2016), Kabinet: geen verbod op salafistische organisaties, "De Volkskrant", 25.02.2016, http://www.volkskrant.nl/binnenland/kabinet-geen-verbod-op-salafistische-organisaties a4251880/ (13.03.2016). 
Haider I. (2016), Pemra advises TV channels to display 'caution'on Saudi-Iran conflict, "The Dawn", 6.01.2016, http://www.dawn.com/news/1231171 (23.01.2016).

Hersh S. (2016), Military to Military, "London Review of Books", 7.01.2016, http://www.lrb.co.uk/ v38/n01/seymour-m-hersh/military-to-military (23.01.2016).

Iran Elections: Reformists Win Voter Support Despite Roadblocks and Irregularities, "Payvand Iran News", 12.03.2016, http:/www.payvand.com/news/16/mar/1054.html (13.03.2016).

Kakar S. F. (2015), KSA-Pakistan ties touch new heights, “Arab News", 14.08.2015, http://www.arabnews.com/saudi-arabia/news/790986 (13.10.2015).

Kaplan D. E., Ekman M., Latif A. (2003), The Saudi Connection - How billions in oil money spawned a global terror network, "US News \& World Report", 15.12.2003, http:/www.phibetaiota.net/2004/12/2004-kaplan-us-the-saudi-connection-how-billions-in-oil-money-spawneda-global-terror-network/ (16.07.2010).

Khairul A. M. (2016), Hisham: IS threat a reality of life, "New Straits Times", 16.01.2016.

Maloney S. (2008), Iran's Long Reach: Iran as a Pivotal State in the Muslim World, United States Institute of Peace, No. 48, Washington DC.

'Members' surprised by Saudi anti-terror coalition plan, "BBC News", 16.12.2015, http://www.bbc.co.uk/ news/world-middle-east-35114060 (23.01.2016).

Moin B. (2015), Khomeini: Life of the Ayatollah, New York: Kindle edition.

Nader S. (2015), Saudi anti-terrorism coalition raises eyebrows in Lebanon, "Al-Monitor", 29.12.2015, http://www.al-monitor.com/pulse/originals/2015/12/lebanon-saudi-islamiccoaltion-hezbollah-hariri.html?utm_source $=$ Al-Monitor+Newsletter $+\% 5 \mathrm{BEnglish} \% 5 \mathrm{D} \& u$ utm campaign $=$ a315908cf7-December_30_2015\&utm_medium $=$ email\&utm_term=0_28264b27a0 a315908cf7-93078213 (23.01.2016).

Nazer F. (2015), Is Saudi Arabia building an 'Islamic NATO?', "Al-Monitor", 20.12.2015, http://www.al-monitor.com/pulse/originals/2015/12/saudi-nato-islamic-terrorism-isis-assadsunni-shiite.html?utm_source $=\mathrm{Al}-\mathrm{Monitor}+$ Newsletter $+\% 5 \mathrm{BEnglish} \% 5 \mathrm{D} \& u$ utm_campaign $=$ 2353947bf2-December_21_2015\&utm_medium=email\&utm_term=0_28264b27a0-2353947 bf2-93078213 (23.01.2016).

Obaid N. (2015a), Only Saudi Arabia can defeat Isis, "The Guardian", 22.10.2015, http://www.theguardian.com/commentisfree/2015/dec/22/saudi-arabia-isis-us-terrorists-coalition?CMP= twt_gu (23.01.2016).

Obaid N. (2015b), Why Saudis formed anti-terror coalition, "CNN", 22.12.2015, http:/edition.cnn.com/2015/12/22/opinions/obaid-saudi-coalition-vs-terror/index.html (23.01.2016).

Pollock D. (2016), Facts and Fictions: A Defense of the U.S.-Saudi Relationship, "Fikra Forum", 21.01.2016, http://fikraforum.org/?p=8482 (23.01.2016).

Racine J. (2016), Pakistan's difficult neighbours, "Le Monde Diplomatique", 03.2016, https://mondediplo.com/2016/03/08pakistan (23.03.2016).

Razoux P. (2015), The Iran-Iraq War, Kindle edition, Cambridge.

Rosen A. (2016), How Saudi Arabia 'pulled a proxy out from under Iran's wing', "Business Insider", 10.01.2016, http://www.businessinsider.sg/how-saudi-arabia-pulled-a-proxy-out-from-underirans-wing-2016-1/ (23.01.2016).

Saudi Arabia could build strong relations with Iran if it changes its policies (2016), "Daily Sabah", 10.03.2016, http://www.dailysabah.com/mideast/2016/03/10/saudi-arabia-could-build-strongrelations-with-iran-if-it-changes-its-policies (11.03.2016).

Saudi Arabia Declares Djibouti FM Persona Non Grata (2015), "Tesfa News", 20.05.2015, http://www.tesfanews.net/saudi-arabia-declares-djibouti-fm-persona-non-grata/ (23.01.2016). 
Saudi Arabia: New Terrorism Regulations Assault Rights, "Human Rights Watch", 20.03.2014, https://www.hrw.org/news/2014/03/20/saudi-arabia-new-terrorism-regulations-assault-right $\mathrm{s}(12.10 .2014)$.

Saudi Arabia says 47 executed on terrorism charges, including Shi'ite cleric (2016), Reuters, 2.01.2016, http://www.reuters.com/article/us-saudi-security-idUSKBN0UG03B20160102? feedType=RSS\&feedName=worldNews (23.01.2016).

Saudi Arabia supreme court upholds death sentence on Shia cleric (2015), Reuters, 25.10.2015, http://www.theguardian.com/world/2015/oct/25/saudi-arabia-supreme-court-upholds-deathsentence-on-shia-cleric (23.01.2016).

Saudi Arabia to Sue Twitter User Who Called Poet's Death Sentence 'ISIS-Like' (2015), Reuters, 25.11.2015, http://europe.newsweek.com/saudi-arabia-sue-twitter-user-who-called-poets-deathsentence-isis-398415? $\mathrm{rm}=\mathrm{eu}(23.01 .2016)$.

Saudi extends $\$ 122$ million economic aid to Pakistan, “Al Manar News", 13.03.2016, https://www.almasdarnews.com/article/saudi-extends-122-million-economic-aid-pakistan (13.03.2016).

Saudi TV Host Abdulellah Al-Dosari Celebrates Death of Iranian Pilgrims in Hajj Stampede in Mecca (2015), The Middle East Media Research Institute, 29.10.2015, https://www.youtube.com/watch?v=LGOGrwnf31Q (23.01.2016).

Siegel A. (2015), Sectarian Twitter Wars: Sunni-Shia Conflict and Cooperation in the Digital Age, "Carnegie Endowment for International Peace", 20.12.2015, http://carnegieendowment.org/ 2015/12/20/sectarian-twitter-wars-sunni-shia-conflict-and-cooperation-in-digital-age/in6n (23.01.2016).

Somalia received Saudi aid the day it cut ties with Iran: document (2016), Reuters, 17.01.2016, http://www.reuters.com/article/us-somalia-saudi-iran-idUSKCNOUVOBH (23.01.2016).

Sudan isolation grows as major banks pull out, "Al Jazeera", 14.03.2014, http://www.aljazeera.com/news/ africa/2014/03/sudan-isolation-grows-as-major-banks-pull-out-201431410522391481.html (11.04.2014).

Sudan shuts down Iranian cultural centres, expels diplomat (2014), "Sudan Tribune", 2.09.2014, http://www.sudantribune.com/spip.php?article52254 (12.10.2014).

Toumi H., Saudi Arabia 'to open military base in Djibouti', "Gulf News", 8.03.2016, http://gulfnews.com/news/gulf/saudi-arabia/saudi-arabia-to-open-military-base-in-djibouti-1.1686291 (23.01.2016).

Worth R. F., Saudi Arabia Rejects U.N. Security Council Seat in Protest Move, "The New York Times", 18.10.2013, http://www.nytimes.com/2013/10/19/world/middleeast/saudi-arabiarejects-security-council-seat.html (23.01.2016).

\begin{abstract}
Challenged economically, politically, socially, ideologically and geopolitically, Saudi Arabia is confronting the perfect storm. How it weathers the storm will depend on how it handles the two most existential threats it faces: the rivalry with Iran for hegemony in the Middle East and North Africa (a battle it ultimately will lose), and the inevitable restructuring of the increasingly problematic marriage between the House of Saud and the Wahhabi clergy, proponents of a puritan interpretation of Islam on whom the ruling Al Saud family rely for their legitimacy.
\end{abstract}

Key words: Middle East, Saudi Arabia, Iran, Islam, Jihad 


\section{ARABIA SAUDYJSKA I IRAN: BITWA O HEGEMONIE, KTÓREJ KRÓLESTWO WYGRAĆ NIE MOŻE}

\section{STRESZCZENIE}

Przed Arabią Saudyjską stoją obecnie wyzwania ekonomiczne, polityczne, społeczne, ideologiczne i geopolityczne. To jak władze saudyjskie poradzą sobie z tymi wyzwaniami zależy w dużej mierze od kluczowych zagrożeń: rywalizacji z Iranem o hegemonię na Bliskim Wschodzie i Afryce Północnej (którą ostatecznie przegra) oraz nieuniknionej rekonstrukcji związku między dynastią Saudów a Wahabitami, zwolennikami purytańskiej interpretacji Islamu, na których rodzina Saudów opiera swą władzę.

Slowa kluczowe: Bliski Wschód, Arabia Saudyjska, Iran, Islam, dżihad 